\title{
Specific dose-dependent effects of ethane 1,2-dimethanesulfonate in rat and mouse Leydig cells and non-steroidogenic cells on programmed cell death
}

\author{
F F G Rommerts, L Kühne ${ }^{1}$, G W A van Cappellen ${ }^{1}$, \\ D M Stocco ${ }^{2}$, S R King ${ }^{3}$ and A Jankowska ${ }^{4}$ \\ Department of Internal Medicine, Erasmus Medical Center Rotterdam, PO Box 1738, DR Rotterdam, The Netherlands \\ ${ }^{1}$ Department of Reproduction and Development, Erasmus Medical Center Rotterdam, The Netherlands \\ ${ }^{2}$ Department of Cell Biology and Biochemistry, Texas Tech University Health Sciences Center, Lubbock, Texas, USA \\ ${ }^{3}$ Scott Department of Urology, Baylor College of Medicine, Houston, Texas, USA \\ ${ }^{4}$ Department of Radiobiology and Cell Biology, School of Medicine, Poznan, Poland \\ (Requests for offprints should be addressed to F F G Rommerts; Email: f.rommerts@erasmusmc.nl)
}

\begin{abstract}
The mechanism by which ethane 1,2-dimethanesulfonate (EDS) selectively kills Leydig cells is poorly understood. To characterize further the cell-specific actions of EDS, we studied biochemical and morphological changes during apoptosis in different Leydig cell and non-steroidogenic cell models.

Rat testicular and H540 tumor Leydig cells were killed by 1-2 mM EDS, whereas $20 \mathrm{mM}$ EDS were required for MA-10 cells. This higher concentration of EDS was also necessary for activation of apoptosis in non-steroidogenic Chinese hamster ovary cells, whereas COS-1 monkey kidney cells were resistant. These variable effects of EDS on apoptosis were independent of new protein synthesis and, interestingly, could be delayed by co-incubation with dibutyrl cyclic AMP. Along with cell death, we also observed chromosomal fragmentation and other hallmarks indicative of apoptosis as evidenced by DNA laddering and fluorescent microscopy. Time-lapse photography with
\end{abstract}

a confocal microscope showed that the time of onset, duration and even the sequence of apoptotic events between individual $\mathrm{H} 540$ cells was heterogeneous. When the dose of EDS was gradually increased from 2 to $10 \mathrm{mM}$, the proportion of cells showing normal apoptotic features gradually decreased. Intriguingly, treatment with $10 \mathrm{mM}$ EDS did not result in death for most cells and was marked by an absence of DNA laddering and ultrastructural features of apoptosis and necrosis. However, incubation with $20 \mathrm{mM}$ EDS resulted in necrosis.

These results demonstrated that the effects of EDS on cell survival are not specific to Leydig cells, that different cell types have different sensitivities to EDS and that stimulation of the cAMP pathway may mitigate EDS action. The data obtained with H540 cells further revealed that EDS can induce two types of programmed cell death.

Journal of Endocrinology (2004) 181, 169-178

\section{Introduction}

Ethane 1,2-dimethanesulfonate (EDS) is a glutathionedependent alkylating agent that rapidly diffuses across tissues and selectively inhibits steroid biosynthesis and destroys Leydig cells in the testes in adult rats (Rommerts et al. 1988, Kelce \& Zirkin 1993, for review see Morris 1996). These 'Leydig cell knock-out' rats have been very useful for investigations on the role of Leydig cells in the control of spermatogenesis and the regulation of Leydig cell re-population (Teerds 1996, van Roijen et al. 1997). However, the mechanism by which EDS stimulates cell death remains unknown.

There are a number of unusual features that distinguish EDS-induced apoptosis. First, cell viability and steroido- genesis in other steroidogenic cell types in the adrenal gland and the ovary are apparently unaffected at doses of EDS that completely eliminate Leydig cells in mature rats (Laskey et al. 1994a). Secondly, sensitivity to the drug depends on the age of the Leydig cell type and the species. Isolated rat Leydig tumor cells and normal Leydig cells from mature rats are killed with 0.5-1 mM EDS (Rommerts et al. 1985a, 1988), whereas immature Leydig cells from 28-day-old rats require an approximately fourfold higher dose (Rommerts et al. 1985a, Kelce et al. 1991, Teerds et al. 1992). In addition, Leydig cells from mouse testes are unaffected at concentrations that eliminate these cells in mature rats. A similar resistance is observed in the rabbit and the hamster (Rommerts et al. 1988, Laskey et al. 1994b, Gray et al. 1995). Leydig cells are killed by EDS 
through apoptosis (Morris et al. 1997a, Taylor et al. 1998, 1999), which is potentially linked to activation of the Fas system and caspase 3 (Taylor et al. 1999, Kim et al. 2000). Unfortunately, the molecular basis for EDS action, its selectivity, concentration dependency and biological effects are not understood.

Therefore, to characterize better the cell-specific actions of EDS, we compared the dose-dependent and temporal effects of EDS on programmed cell death (PCD) in different Leydig cell types and in two model non-steroidogenic cell lines through biochemical and morphological analyses.

\section{Materials and Methods}

\section{Materials}

We prepared EDS from ethylene glycol and methane sulfonyl chloride as described by Jackson \& Jackson (1984). The compound was recrystallized twice from methylene chloride to more than $99 \%$ purity as determined by nuclear magnetic resonance and stored in 100-fold concentrated stock solutions in DMSO at $4{ }^{\circ} \mathrm{C}$. The fluorescent nuclear stains Hoechst 33342, propidium iodide (PI) and Syto-16 were purchased from Molecular Probes (Leiden, The Netherlands). Other chemical reagents were obtained from Sigma Chemical Co. (Zwijndrecht, The Netherlands).

\section{Cell culture}

Rat Leydig cells were isolated from testicular tissues from mature and 21- to 23-day-old rats and a transplantable H540 tumor after collagenase dispersion. For normal Leydig cells, rats were irradiated before birth at day 19 of gestation with $1.5 \mathrm{~Gy} \mathrm{X}$-rays to deplete the testes of germinal cells. Approval was obtained from institutional committees for both procedures. After isolation, Leydig cells were maintained in RPMI-1640 medium with $1 \%$ fetal calf serum (FCS) for several hours until they were used for experiments. Under these conditions, Leydig cells remain viable but do not divide and gradually lose their steroidogenic properties over a period of several days. Details of the techniques for obtaining cells as well as characterization of cell composition, viability and steroid production, have been described previously (Rommerts et al. 1985b). After isolation, H540 tumor cells were seeded to the plastic surface and after several hours they appeared as flat cells with large nuclei. Over a period of several days no mitotic cells could be detected.

The MA-10 cell line was a generous gift from Dr Mario Ascoli (University of Iowa, Iowa City, IO, USA) and was grown under standard conditions in RPMI-1640 medium supplemented with $10 \%$ horse serum and $100 \mu \mathrm{g} / \mathrm{ml}$ streptomycin sulfate, $100 \mathrm{IU} / \mathrm{ml}$ penicillin and $2 \mathrm{mM}$ L-glutamate (Ascoli 1981). Normal Chinese hamster ovary $(\mathrm{CHO})$ and COS-1 cells were grown in 1:1 (v/v) Dulbecco's modified Eagle's/Ham's F12 medium supplemented with antibiotics and 10\% and 5\% FCS respectively.

For the experiments, cells were incubated in fresh culture medium containing 1\% FCS in the presence or absence of $1 \mathrm{mM}$ dibutyl cyclic AMP (dbcAMP) and EDS or $100 \mu \mathrm{M}$ cadmium, as a non-specific cytotoxic compound (Selypes et al. 1992). To investigate the effects of inhibition of protein synthesis on apoptosis, cells were incubated with $100 \mu \mathrm{M}$ cycloheximide (CHX).

\section{Characterization of apoptosis}

The biochemical characterization of apoptosis was performed by measuring the fragmentation of DNA after selective cell extraction and agarose gel electrophoresis as described elsewhere (Gong et al. 1994). DNA was visualized by autoradiography after blotting, and hybridization with digested and radiolabeled rat genomic DNA.

For morphological characterization of the cell death process, three fluorescent dyes with limited toxicity were used. Early signs of apoptosis in intact cells at the level of chromatin structure were visualized with $0.1 \mu \mathrm{g} / \mathrm{ml}$ Hoechst 33342 dye in the blue channel (excitation at $365 \mathrm{~nm}$, emission above $410 \mathrm{~nm}$ ). Movement of phosphatidylserine from the inner to the outer layer of the plasma membrane (typical of apoptosis) was monitored in the green channel (excitation at 450-490 nm, emission above $520 \mathrm{~nm}$ ) by co-incubation with $2.5 \mu \mathrm{g} / \mathrm{ml}$ fluorescein isothiocyanate (FITC)-conjugated annexin V (Boehringer Ingelheim, Alkmaar, The Netherlands), which specifically binds this phospholipid (van Engeland et al. 1996). Permeabilization of the plasma membrane, which occurs during necrosis or later phases of apoptosis, was indicated through the use of $0 \cdot 1 \mu \mathrm{g} / \mathrm{ml}$ of the DNA stain PI, using the red channel (excitation at 530-560 nm, emission above $580 \mathrm{~nm}$ ). Digitally captured fluorescent images were converted to gray scale to better represent variations in intensity after printing. The degree of apoptosis and/or necrosis was determined by scoring the percentage of cells with apoptotic or necrotic features. The threshold dose for induction of apoptosis was defined as the minimum dose of EDS required to cause a 10-20\% increase in the number of apoptotic (non-necrotic) cells after an incubation period of $20 \mathrm{~h}$.

The kinetics of the apoptosis process in individual cells (initiation and duration of substages) was measured by time-lapse recordings using a Zeiss CLSM 410 confocal laser-scanning microscope (Carl Zeiss, Weesp, The Netherlands). A cover glass with H540 tumor cells attached was mounted on an aluminum holder with nontoxic rubber rings in a temperature-controlled aluminum block. Additional heating of the objective was necessary when immersion oil was used, to correct for cooling of the cover glass in contact with the lens. Chromatin in intact 


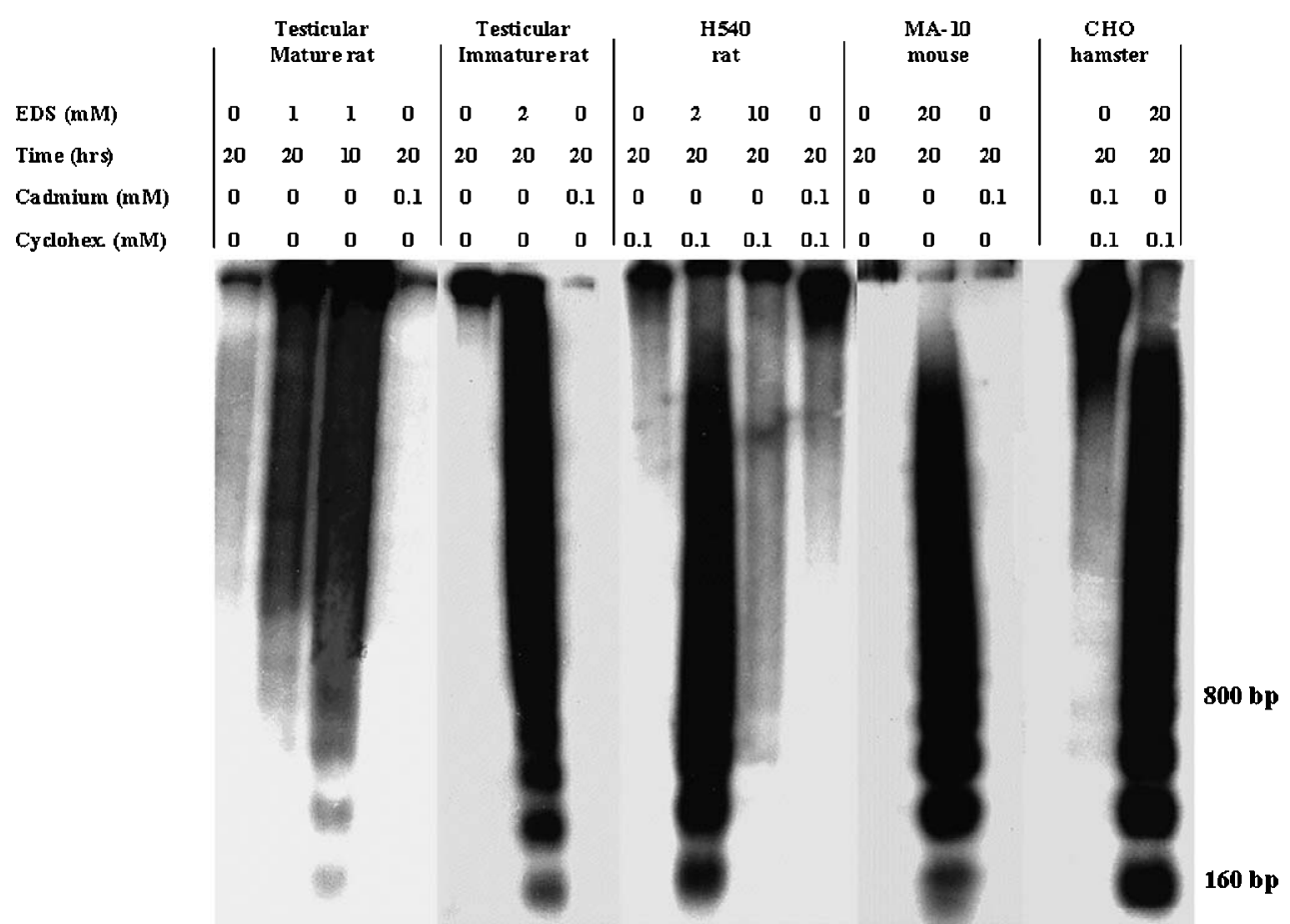

Figure 1 EDS induces apoptotic chromosomal breakdown in mature and immature testicular Leydig cells and in tumor-derived Leydig cells as well as in non-steroidogenic cells at different threshold doses. Southern blot analysis of DNA from Leydig cells and $\mathrm{CHO}$ cells incubated with $\mathrm{mM}$ doses of EDS or $100 \mu \mathrm{M}$ cadmium for 10-20 h are shown. Experiments with $\mathrm{H} 540$ and $\mathrm{CHO}$ cells were carried out in the presence of $0.1 \mathrm{mM}$ cycloheximide (CHX). The position of two DNA markers is shown on the right side of the figure. Representative results from two to three different experiments for each cell type are given.

cells was visualized using $0 \cdot 1 \mu \mathrm{g} / \mathrm{ml}$ Syto-16 dye (excitation at $488 \mathrm{~nm}$, emission at $515-540 \mathrm{~nm}$ ), since u.v. excitation was not possible in this system.

\section{Analysis of ultrastructure}

H540 cells were fixed at room temperature on culture dishes with 2.5\% glutaraldehyde (Polysciences, Eppelheim, Germany) in $0 \cdot 1 \mathrm{M}$ phosphate buffer, $\mathrm{pH} 7 \cdot 4$, and postfixed in $1 \% \mathrm{OsO}_{4}$ (Sigma Chemical Co.) in phosphate buffer. After dehydration, cells were embedded directly on the plates using Epon (Polysciences). Ultrathin sections of cells were obtained by cutting horizontally to the bottom of the culture dish. Sections were stained with uranyl acetate and lead citrate and examined using a JEM $100 \mathrm{~S}$ transmission electron microscope (JEOL, Peabody, MA, USA).

\section{Results}

Cell death and chromatin breakdown

To examine the biochemical aspects of the induction of apoptosis in various cells by EDS, we first tested for the presence of DNA ladders, which is indicative of apoptosisrelated chromosomal breakdown (Fig. 1). While control cells exhibited no characteristic chromosomal degradation, DNA laddering was observed in Leydig cells from mature rats after $10-20 \mathrm{~h}$ of incubation with $1 \mathrm{mM}$ EDS. In contrast, a concentration of $2 \mathrm{mM}$ EDS was required to cause DNA laddering in testicular Leydig cells from immature rats and in $\mathrm{H} 540$ cells.

The EDS-induced laddering in H540 cells was unaffected by the presence of CHX, indicating that the process was independent of new protein synthesis. Incubation for $20 \mathrm{~h}$ with CHX alone did not cause any cell death, but an increasing number of cells did finally display apoptotic features after $48 \mathrm{~h}$ (data not shown). Surprisingly, when cells were incubated with $10 \mathrm{mM}$ EDS, no DNA laddering was observed.

MA-10 cells were more resistant to the effects of EDS. Unlike rat Leydig cells, $20 \mathrm{mM}$ EDS were required to induce substantial levels of DNA laddering.

Non-steroidogenic CHO cells were also susceptible to EDS. Similar to MA-10 cells, fragmentation of DNA was observed in cells treated with $20 \mathrm{mM}$ EDS, even in the presence of CHX. Due to solubility problems, higher EDS concentrations were not tested. 
By contrast, necrosis induced by $100 \mu \mathrm{M}$ cadmium did not result in DNA laddering in any of the cell types tested.

\section{Cell death and morphology}

To determine whether the unusual and differing responses of cells to EDS reflected unique intracellular changes, we performed various morphological analyses. Since it is difficult to prepare homogenous Leydig cells with consistent properties from testes, we focused our studies on the tumor cell lines.

MA-10 cells and non-steroidogenic cells MA-10 cells were less sensitive to the effects of EDS than rat Leydig cells. Treatment with $10 \mathrm{mM}$ EDS resulted in only variable levels of apoptosis. However, a twofold higher concentration of EDS caused over $90 \%$ of the cells to enter apoptosis, with many cells detaching from the culture dish. Control cells exhibited normal staining with Hoechst 33342 dye without labeling by either PI or annexin V, which is indicative of the presence of extracellular phosphatidylserine in intact plasma membranes (data not shown). In contrast, early apoptotic MA-10 cells displayed chromatin clumping and intense staining with Hoechst 33324 dye (Fig. 2A1), an absence of PI staining (Fig. 2A2) (and thus no necrosis), and annexin $\mathrm{V}$ binding (Fig. 2A3).

Co-incubation with CHX did not influence the phenotype of apoptosis induced by EDS, but did tend to increase the rate, whereas CHX alone had only minor effects in the first $20 \mathrm{~h}$. Interestingly, co-incubation of cells with EDS and $1 \mathrm{mM}$ dbcAMP resulted in only limited apoptosis in the same time-period (Fig. 2B), with many more cells entering apoptosis only after $30 \mathrm{~h}$ incubation (data not shown).

Apoptosis was also induced in $\mathrm{CHO}$ cells with a threshold dose of EDS between 10 and $20 \mathrm{mM}$ over $20 \mathrm{~h}$. The morphological characteristics were similar to those seen in MA-10 Leydig cells, except that almost all of the cells that underwent apoptosis remained attached to the culture dish. Finally, as with MA-10 Leydig cells, dbcAMP delayed the onset of apoptosis for the first $20 \mathrm{~h}$ (data not shown).

Another non-steroidogenic cell type, COS-1 cells, displayed none of the typical morphological features of apoptosis, even when incubated with $20 \mathrm{mM}$ EDS. Cells did round up, detach from the surface of the culture dish and clump together, but they remained impermeable to PI for at least $20 \mathrm{~h}$ (data not shown).

H540 cells Since the H540 cells showed a surprising anomalous response when the dose of EDS was elevated from 2 to $10 \mathrm{mM}$ EDS, these cells were investigated in greater detail. We first compared necrotic cell death, as elicited by cadmium, to the effects of EDS using several fluorescent probes.

After the addition of $0.1 \mathrm{mM}$ cadmium, necrosis was characterized by an initial cell rounding and increased staining of DNA by Hoechst 33342 dye (Fig. 2C1). This was followed by a gradual loss of plasma membrane integrity over the next $10 \mathrm{~h}$ as demonstrated by an increase in PI staining of DNA (Fig. 2C2) and annexin V binding of externalized intracellular phosphatidylserine (Fig. 2C3). After $20 \mathrm{~h}$, all cells lost membrane integrity without detectable changes in chromatin distribution (Fig. 2D).

In contrast, EDS-induced apoptosis had completely different features. After the addition of $2 \mathrm{mM}$ EDS, cells began to round up with a corresponding reduction in nuclear diameter within $3 \mathrm{~h}$. Clear chromatin condensation was observed after $6-10 \mathrm{~h}$. This response was heterogeneous, with a mixed population of cells undergoing apoptosis together with cells that had not yet started the rounding process (Fig. 2E1). Cells with condensed chromatin contained more intensely stained DNA than non-responding cells (Fig. 2E1), were impermeable to PI (Fig. 2E2) and stained with FITC-conjugated annexin V (Fig. 2E3). In most cells, changes in the nuclei and the plasma membrane occurred in parallel, but there were some cells that displayed only one marker of apoptosis. This suggests some heterogeneity in the sequence of apoptotic events.

After $20 \mathrm{~h}$ of incubation with $2 \mathrm{mM}$ EDS, nearly all cells exhibited fragmented chromatin, characteristic of apoptosis and consistent with the results of the chromatin breakdown analyses (Fig. 2F). This apoptotic process was unaltered in the presence of CHX (data not shown). Surprisingly, addition of $1 \mathrm{mM}$ dbcAMP to the culture media suppressed or delayed chromatin condensation (Fig. $2 \mathrm{H})$. Only at later time-points did these cells finally undergo apoptosis (data not shown).

The heterogeneity of the apoptotic response was further documented by time-lapse photography using a confocal microscope and the DNA stain Syto-16. We found that the greatest alterations in chromatin structure occurred between 6 and $18 \mathrm{~h}$ after the start of the incubation. There was a gradual change in chromatin structure from a continuous distribution to an increasingly condensed peripheral localization and, finally, to fragmentation. This chromatin rearrangement was used to identify four substages of the initial apoptotic process. The results of observations for 15 individual cells over this time period are shown schematically in Fig. 3. Changes in chromatin during apoptosis in H540 cells were found to be heterogeneous in both the onset and duration of each substage and the total length of time over which this occurred.

Concentrations of EDS higher than $2 \mathrm{mM}$ elicited a different type of heterogeneity. Between 2 and $10 \mathrm{mM}$ EDS, an increasing number of cells displayed an anomalous non-necrotic, non-apoptotic response, while at $20 \mathrm{mM}$ EDS there were many signs of necrosis within $20 \mathrm{~h}$. This anomalous response also occurred even when protein synthesis was inhibited by co-incubation with CHX. Consistent with the observed lack of DNA laddering, most of the cells incubated in the presence of $10 \mathrm{mM}$ 

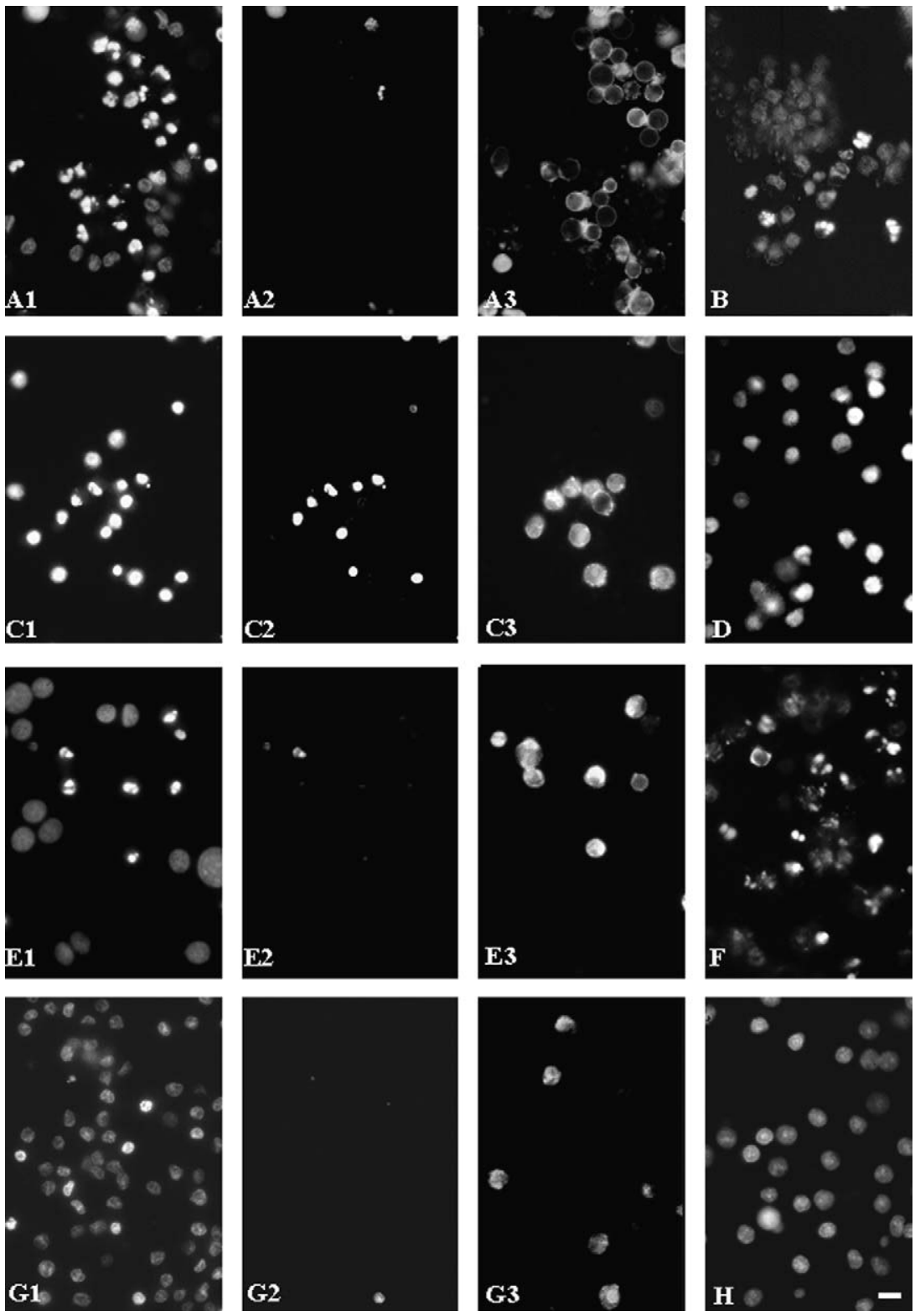

Figure 2 Fluorescent microscopy images of cell death in MA-10 cells (first row) and H540 cells (all other rows) presented in gray scale. Columns 1 and 4, cells stained with blue Hoechst 33342; column 2, cells stained with red Pl; column 3, cells stained with green FITC-conjugated annexin V. Images with the same letters are taken from one microscopic field in three different channels. Different letters indicate different incubation conditions. Row 1: apoptosis in MA-10 cells induced by $20 \mathrm{mM}$ EDS after $20 \mathrm{~h}$ in the absence (A) or presence (B) of $1 \mathrm{mM}$ dbcAMP. Similar staining patterns in $\mathrm{A} 1$ and $\mathrm{A} 3$ but not A2 indicate apoptosis. B, a few cells with fragmented chromatin.

Row 2: necrosis in H540 cells induced by cadmium after $10 \mathrm{~h}$ (C) and $20 \mathrm{~h}$ (D). Similar staining patterns of cells in C1, C2 and C3 indicate necrosis. D, no cells with fragmented chromatin.

Row 3: apoptosis in H540 cells induced by 2 mM EDS after $10 \mathrm{~h}$ (E) and $20 \mathrm{~h}$ (F). Similar staining patterns of cells in E1 and E3 but not E2 indicate apoptosis. F, many cells with fragmented chromatin. Row 4: alternative cell death program in $\mathrm{H} 540$ cells induced by $10 \mathrm{mM}$ EDS after $20 \mathrm{~h}(\mathrm{G})$. H540 cells incubated with $2 \mathrm{mM}$ EDS and $1 \mathrm{mM}$ dbcAMP for $20 \mathrm{~h}(\mathrm{H})$. Absence of similarities between staining patterns in G1, G2 and G3 indicates abnormal cell death programme. $\mathrm{H}$, no cells with fragmented chromatin (compare with $\mathrm{F}$ ). Bar $=5 \mu \mathrm{m}$. 


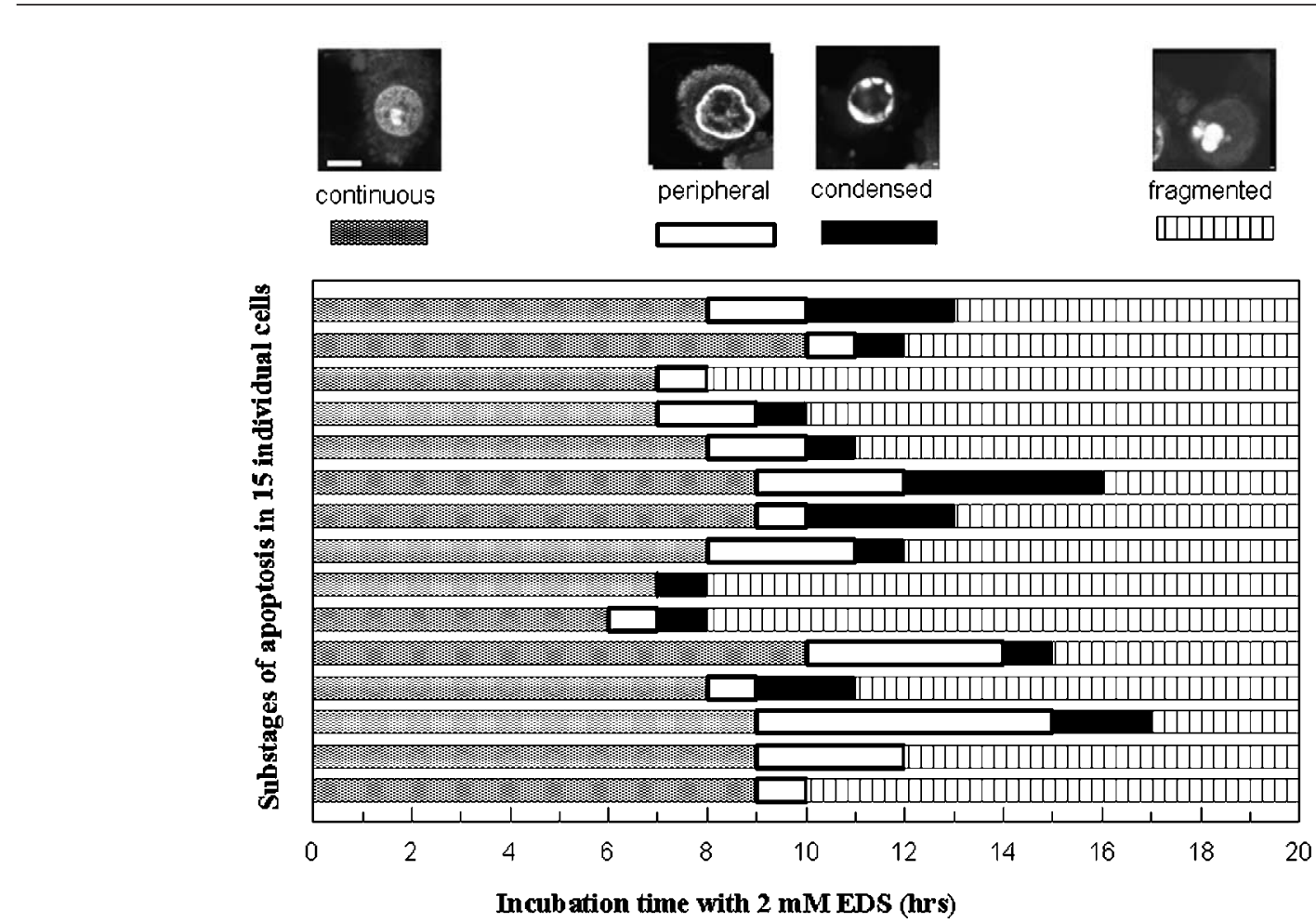

Figure 3 Leydig cell populations respond heterogeneously to EDS treatment. Time-lapse recordings of EDS-induced apoptosis in 15 individual H540 cells stained with Syto-16. Images were taken each hour with a confocal laser-scanning microscope in one plane between 6 and $18 \mathrm{~h}$ after the addition of $2 \mathrm{mM}$ EDS. The chromatin pattern was used to identify four morphological stages of the apoptotic process: continuous, peripheral, condensed and fragmented chromatin. Bar $=5 \mu \mathrm{m}$.

EDS exhibited no change in the morphology of Hoechst 33343-stained chromatin, although they did round up over the 20-h incubation period (Fig. 2 G1). Cells appeared to still remain viable after this time, with only a few taking on necrotic features (indicated by the limited number of cells stained with PI (Fig. 2 G2)), or apoptotic features (indicated by the paucity of annexin $\mathrm{V}$ labeling (Fig. 2 G3)). More than $30 \mathrm{~h}$ after the start of the experiment, these abnormally responding Leydig cells finally showed signs of necrotic cell death.

To characterize further this anomalous response, the ultrastructure of these cells was compared with those of control and typical apoptotic cells. Control cells displayed an irregular surface (Fig. 4a), normal nuclei with a dense matrix (Fig. 4a and d), mitochondria with good, visible cristae and a cytoplasm with normal-appearing constituents (Fig. $4 \mathrm{~g}$ ). On the other hand, cells incubated with $2 \mathrm{mM}$ EDS displayed all the features of apoptotic cells, including clumping of densely stained chromatin with sharp boundaries (Fig. 4b and e) and a light mitochondrial matrix with clear signs of destruction of the interior structure (Fig. $4 \mathrm{~h}$ ). In addition, many small cytoplasmic vesicles were observed (Fig. 4b, e and h) and the surfaces of these apoptotic cells were smooth (Fig. 4b). In cells exposed to $10 \mathrm{mM}$ EDS, two different cell morphologies were observed. A few cells showed features of apoptosis, such as condensed chromatin and damaged mitochondria, although the number and distribution of vacuoles appeared to be different from normal apoptotic cells (data not shown). The majority of cells, however, showed many similarities with control cells (Fig. 4c). The complete absence of chromatin condensation was especially striking (Fig. 4f). These cells also contained vacuoles and many protrusions in their surfaces in possibly greater abundance than in control cells (Figs 4c and 5a). Many condensed, multi-membranous vesicles were also observed (arrows in Figs $4 c, 4 i$ and $5 b$ ). Mitochondria were elongated and appeared less dense and lower in number when compared with control cells (Figs. 4i and 5b). Altogether, $10 \mathrm{mM}$ EDS-treated H540 cells exhibited a peculiar ultrastructure that was generally closer in appearance to intact cells than cells undergoing apoptosis.

\section{Discussion}

The distinctive manner by which EDS selectively kills Leydig cells in vivo is unclear. In line with its unusual 

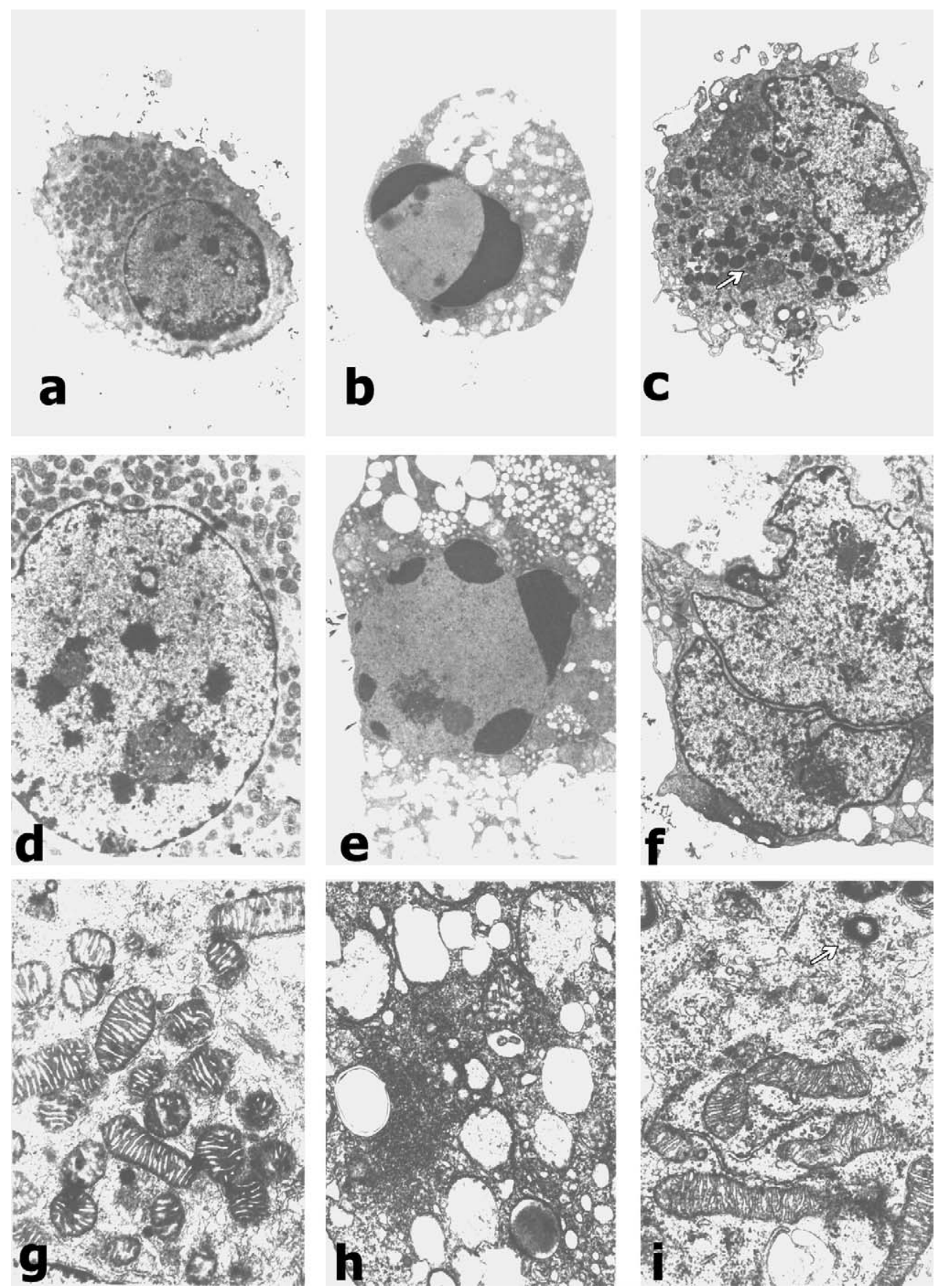

Figure 4 Differing effective concentrations of EDS evoke differing responses in Leydig cells. Ultrastructure of H540 cells $(\mathrm{a}-\mathrm{c})$, nuclei $(\mathrm{d}-\mathrm{f})$ and mitochondria $(\mathrm{g}-\mathrm{i})$ after incubation for $20 \mathrm{~h}$ in the presence of $\mathrm{CHX}$ without $(\mathrm{a}, \mathrm{d}, \mathrm{g})$ or with $2(\mathrm{~b}, \mathrm{e}, \mathrm{h})$ or $10(\mathrm{c}, \mathrm{f}, \mathrm{i}) \mathrm{mM}$ EDS. See Results for a full description of the morphology. Magnifications: a-c, $\times 2700 ; d-f, \times 3700 ; g-i, \times 15000$.

action, the present studies yielded some unusual observations. Incubation with EDS dose-dependently triggered apoptosis in all Leydig cells examined, but at different threshold concentrations. Cell death was also induced in non-steroidogenic $\mathrm{CHO}$ cells, whereas COS-1 cells were essentially refractory to EDS. Thus, EDS can induce apoptosis in cell types other than Leydig cells. This is consistent with previously published data, although this 


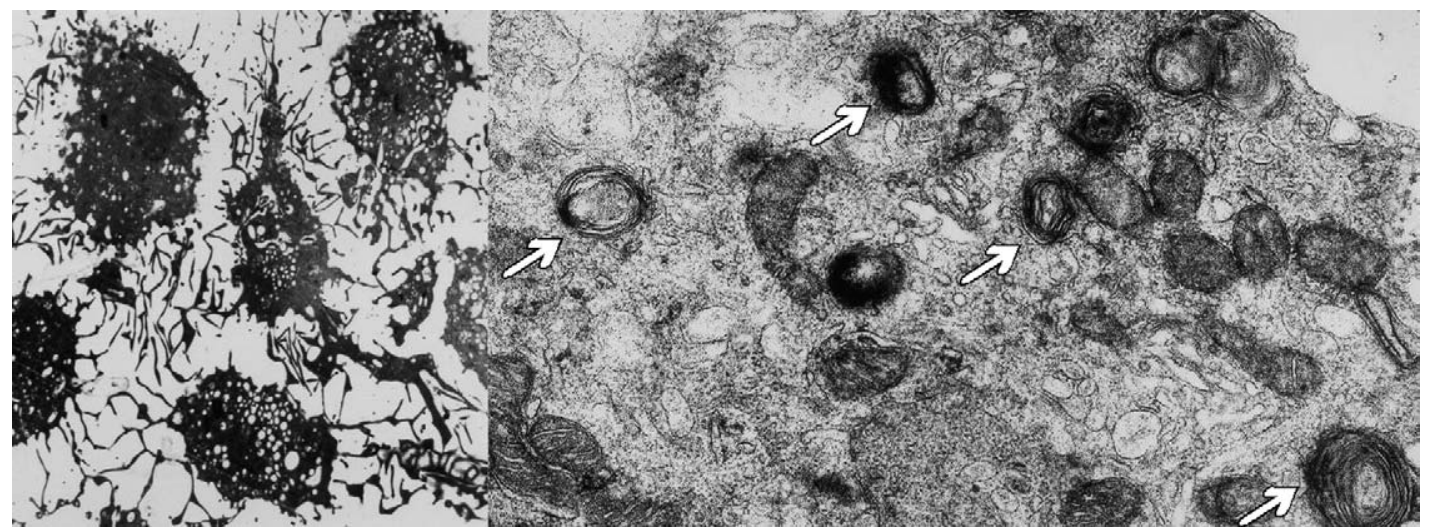

Figure 5 Treatment of $\mathrm{H} 450$ cells with $10 \mathrm{mM}$ EDS and $\mathrm{CHX}$ over $20 \mathrm{~h}$ results in unique changes in the plasma membrane (a) and mitochondria, see white arrows (b). See Results for a full description of the morphology. Magnifications: a, × 1000; b, × 20000 .

was primarily observed only after longer post-exposure periods (Klinefelter et al. 1990, Laskey et al. 1994, Morris et al. 1997b, Plecas et al. 1997, King et al. 1998). The different threshold concentrations for induction of PCD in various cell types could help to explain how administration of twice the effective dose $(200 \mathrm{mg} / \mathrm{kg})$ of EDS to rats can be fatal (Morris 1996). This remarkable dose-dependent shift in lethality may arise from the extinction of physiologically essential cell types that are slightly less sensitive to EDS than Leydig cells.

EDS-induced PCD was accompanied by DNA ladder formation and changes in nuclear morphology - initial clumping and later fragmentation of chromatin. These qualitative changes in chromatin occurred in parallel with increases in DNA staining intensity. While chromatin staining increased, there was a concomitant increase in annexin $\mathrm{V}$ binding and thus externalization of phosphatidylserine on intact plasma membranes, due to scramblase activity and inhibition of aminophospholipid translocase (Raggers et al. 2000). At later time-points, the integrity of the plasma membrane was lost as reflected by the influx of PI.

Activation of these cell death processes is not mediated by alterations in gene expression since inhibition of protein synthesis by CHX did not prevent cells from entering apoptotic pathways (present study, Kelce \& Zirkin 1993). Thus, the importance of EDS-induced up-regulation of Fas ligand and Fas receptor is unclear (Taylor et al. 1999). It is also uncertain whether increases in the levels of these proteins represent an essential step in the EDS-activated sequence of events, or if this is simply one of many changes that accompany apoptosis. The independence of apoptosis from new protein synthesis indicates that the early effects of EDS that commit the cell to death are most likely mediated by modifications of existing proteins through glutathione conjugation and alkylation (Kelce \& Zirkin 1993, Kelce 1994) and proteolytic breakdown by caspases
(Kim et al. 2000). In this connection it is interesting to note that in mature rat Leydig cells in the presence of reduced glutathione levels, 20-fold higher concentrations of EDS are required to alkylate proteins, inhibit steroidogenesis and induce cell death (Kelce 1994).

Differences in specificity to the drug may be related to sensitivity to such modifications (Rommerts et al. 1985a) or the uniqueness of critical alkylated pro-apoptotic proteins to EDS-responding cells. Since co-incubation with dbcAMP significantly delays apoptosis, the changes induced by these modifications are probably also influenced by protein phosphorylation. Studies in other cell types indicate that activation of the cAMP second messenger pathway can have either pro-apoptotic effects or rescue cells from death, although the mechanism for these actions remains unclear (Saavedra et al. 2002).

Uncertainties about the molecular nature of apoptosis are magnified when the heterogeneity of responses within a particular cell culture is taken into account. Using time-lapse photography, variable times of initiation and duration of substages of apoptosis were observed and alterations in plasma membrane and nuclear morphology were not always synchronous. These observations led to the conclusion that the underlying biochemical reactions involved in EDS-induced apoptosis proceed in a nonlinear order and with differing kinetics. Various explanations for the heterogeneity of cellular responses to apoptotic stimuli, such as influences of the paracrine environment and progression through the cell cycle, have previously been advanced. An initial report suggested that a cell cycle-dependent pathway for EDS action in Leydig cells may exist (Woolveridge et al. 2001), but this would not account for the present observations, since H540 cells are non-mitotic in culture.

A dose dependence for the type of cell death induced in H540 cells was also found. At concentrations of EDS higher than $2 \mathrm{mM}$, an increasing proportion of Leydig cells 
showed 'resistance' to the normal apoptosis program, with an absence of chromatin condensation, formation of DNA ladders and annexin $\mathrm{V}$ binding, while the number of abnormally responding cells increased. At $10 \mathrm{mM}$ EDS, almost all cells contained normal uncondensed chromatin together with unusual changes in the ultrastructure of the mitochondria, plasma membrane and cytoplasm. In fact, there appeared to be a higher level of protrusions on the plasma membrane when compared with controls. It is possible that high levels of EDS may block an essential step in PCD, such as activation of the nuclear apoptotic pathway (Susin et al. 2000) or activation of pro-apoptotic caspase activity typically resulting in chromatin condensation, loss of cellular protrusions and finally disintegration (Häcker 2000). Thus, the cells are essentially left suspended between two different death pathways with unknown regulatory properties. A few alternative morphological forms of PCD have been described, such as oncosis and paraptosis (Majno \& Joris 1995, Nicotera et al. 1999, Sperandio et al. 2000). Future studies will determine whether our cell death pattern may fit with one of these alternative forms of apoptosis or constitute a novel type of PCD.

In summary, this comparative study of the dose-related effects of EDS on different cell types has revealed a broad spectrum of specific biological effects. We first observed that EDS induced cell death in both steroidogenic and non-steroidogenic cell types independent of new protein synthesis. Individual cell types not only had different sensitivities to EDS but, even at a fixed concentration of EDS within one cell population, PCD responses were very heterogeneous. Furthermore, different concentrations of EDS surprisingly elicited different types of cell death. Interestingly, stimulation of the cAMP pathway appeared to protect or prolong cell survival. Altogether, these data provide further insight into the phenotypic pathways by which EDS promotes PCD.

\section{Acknowledgements}

This research was supported by grants from the National Institute of Health (NIH) HD17481 and the Robert A Welch Foundation to D M S and NIH DK61548 and the Lalor Foundation to S R K.

\section{References}

Ascoli M 1981 Characterization of several clonal lines of cultured Leydig tumor cells: gonadotropin receptors and steroidogenic responses. Endocrinology 108 88-95.

van Engeland M, Ramaekers FC, Schutte B \& Reutelingsperger CP 1996 A novel assay to measure loss of plasma membrane asymmetry during apoptosis of adherent cells in culture. Cytometry 24 131-139.

Gong J, Traganos F \& Darzynkiewicz Z 1994 A selective procedure for DNA extraction from apoptotic cells applicable for gel electrophoresis and flow cytometry. Analytical Biochemistry 218 314-319.
Gray LE, Klinefelter G, Kelce W, Laskey J, Ostby J \& Ewing L 1995 Hamster Leydig cells are less sensitive to ethane dimethanesulfonate when compared to rat Leydig cells both in vivo and in vitro. Toxicology and Applied Pharmacology 130 248-256.

Häcker G 2000 The morphology of apoptosis. Cell and Tissue Research $3015-17$.

Jackson CM \& Jackson H 1984 Comparative protective actions of gonadotrophins and testosterone against the antispermatogenetic action of ethane dimethanesulfonate. Journal of Reproduction and Fertility 71 393-401.

Kelce WR 1994 Buthione sulfoximine protects the viability of rat adult Leydig exposed to ethane dimethanesulfonate. Toxicology and Applied Pharmacology 125 237-246.

Kelce WR \& Zirkin BR 1993 Mechanism by which ethane dimethanesulfonate kills adult rat Leydig cells: involvement of intracellular glutathione. Toxicology and Applied Pharmacology 120 80-88.

Kelce WR, Zirkin BR \& Ewing LL 1991 Immature rat Leydig cells are intrinsically less sensitive than adult Leydig cells to ethane dimethanesulfonate. Toxicology and Applied Pharmacology 111 189-200.

Kim, JM, Luo, L \& Zirkin BR 2000 Caspase-3 activation is required for Leydig cell apoptosis induced by ethane dimethanesulfonate. Endocrinology 141 1846-1853.

King SR, Rommerts FF, Ford SL, Hutson JC, Orly J \& Stocco DM 1998 Ethane dimethane sulfonate and $\mathrm{NNN}^{\prime} \mathrm{N}^{\prime}$-tetrakis-(2pyridylmethyl)ethylenediamine inhibit steroidogenic acute regulatory (StAR) protein expression in MA-10 Leydig cells and rat Sertoli cells. Endocrine Research 24 469-478.

Klinefelter GR, Laskey JW, Roberts NR, Slott V \& Suarez JD 1990 Multiple effects of ethane dimethanesulfonate on the epididymis of adult rats. Toxicology and Applied Pharmacology 105 271-287.

Laskey JW, Kelce WR, Klinefelter GR, Gray LE \& Ewing LL 1994a Distribution of $\left[{ }^{14} \mathrm{C}\right]$ ethane dimethanesulfonate in immature and adult male rats following an acute exposure. Fundamental Applied Toxicology 22 319-327.

Laskey JW, Klinefelter GR, Kelce WR \& Ewing LL $1994 b$ Effects of ethane dimethanesulfonate (EDS) on adult and immature rabbit Leydig cells: comparison with EDS-treated rat Leydig cells. Biology of Reproduction $\mathbf{5 0}$ 1151-1160.

Majno G \& Joris I 1995 Apoptosis, oncosis and necrosis. An overview of cell death. American Journal of Pathology 146 3-15.

Morris AJ, Taylor MF \& Morris ID 1997a Leydig cell apoptosis in response to ethane dimethanesulfonate after both in vivo and in vitro treatment. Journal of Andrology 18 274-280.

Morris ID 1996 Leydig cell toxicology. In The Leydig Cell, pp 574-596. Eds AH Payne, MP Hardy \& LD Russell. Vienna: Cache River Press.

Morris ID, Lendon RG, Waters C, Naylor G \& Jones N 19976 Thymic regression and apoptosis in the rat after treatment with the Leydig cell cytotoxin ethylene dimethanesulfonate (EDS). Toxicology $12019-27$.

Nicotera P, Leist M \& Manzo L 1999 Neuronal cell death: a demise with different shapes. Trends in Pharmacological Sciences 20 46-51.

Plecas B, Glavaski A, Savic V, Hristic M, Duric D \& Solarovic T 1997 Effects of ethane dimethanesulfonate on the structure of adult male rat adrenal cortex. Pharmacalogical Research 35 541-546.

Raggers RJ, Pomorski T, Holthuis JCM, Kälin N \& van Meer G 2000 Lipid traffic: the ABC of transbilayer movement. Traffic 1 226-234.

Van Roijen JH, Ooms MP, Weber RF, Brinkmann AO, Grootegoed JA \&Vreeburg JT 1997 Comparison of the response of rat testis and accessory sex organs to treatment with testosterone and the synthetic androgen methyltrienolone (R1881). International Journal of Andrology 18 51-61.

Rommerts FFG, Grootenhuis AJ, Hoogerbrugge JW \& van der Molen HJ $1985 a$ Ethane dimethane sulfonate (EDS) specifically inhibits 
LH-stimulated steroidogenesis in Leydig cells isolated from mature rats but not in cells from immature rats. Molecular and Cellular Endocrinology 42 105-111.

Rommerts FFG, Molenaar R \& van der Molen HJ $1985 b$ Preparation of isolated Leydig cells. Methods in Enzymology 109 275-288.

Rommerts FFG, Teerds KJ \& Hoogerbrugge JW 1988 In vitro effects of ethylene-dimethane sulfonate (EDS) on Leydig cells: inhibition of steroid production and cytotoxic effects are dependent on species and age of rat. Molecular and Cellular Endocrinology 55 87-94.

Saavedra AP, Tsygankova OM, Prendergast GV, Dworet JH, Cheng G \& Meinkoth JL 2002 Role of cAMP, PKA and Rap1A in thyroid follicular cell survival. Oncogene 21 778-788.

Selypes A, Serenyi P, Boldog I, Bokros F \& Takacs S 1992 Acute and long term genotoxic effect of $\mathrm{CdCl}_{2}$ on testes of mice. Journal of Toxicology and Environmental Health 36 401-409.

Sperandio S, de Belle I \& Bredsen DE 2000 An alternative, nonapoptotic form of programmed cell death. PNAS $\mathbf{9 7}$ 14376-14381.

Susin SA, Daugas E, Ravagnan L, Samejima K, Zamzami N, Loeffler M, Costantini P, Ferri KF, Irinopoulou T, Prevost M, Brother G, Mak TW, Penninger J, Earnshaw WC \& Kroemer G 2000 Two distinct pathways leading to nuclear apoptosis. Journal of Experimental Medicine 192 571-579.

Taylor MF, Woolveridge I, Metcalfe A, Streuli CH, Hickman JA \& Morris ID 1998 Leydig cell apoptosis in the rat testes after the cytotoxin ethane dimethanesulfonate: role of the Bcl-2 family members. Journal of Endocrinology 157 317-326.
Taylor MF, de Boer-Brouwer M, Woolveridge I, Teerds KJ \& Morris ID 1999 Leydig cell apoptosis following the administration of ethane dimethanesulfonate to the adult male rat is a Fas-mediated process. Endocrinology 140 3797-3804.

Teerds KJ 1996 Regeneration of Leydig cells after depletion by EDS: a model for postnatal Leydig cell renewal. In The Leydig Cell, pp 203-220. Eds AH Payne, MP Hardy \& LD Russell. Vienna: Cache River Press.

Teerds KJ, de Rooij DG, Wensing CJG \& Rommerts FFG 1992 Hormone-induced resistance of rat Leydig cells to the cytotoxic effects of ethane-1,2-dimethane sulfonate. Journal of Endocrinology 134 85-90.

Woolveridge I, Taylor MF, Rommerts FF \& Morris ID 2001 Apoptosis-related gene products in differentiated and tumorigenic rat Leydig cells and following regression induced by the cytotoxin ethane dimethanesulfonate. International Journal of Andrology 24 $56-64$.

Received 14 January 2004

Accepted 20 January 2004

Made available online as an

Accepted Preprint 26 January 2004 